\title{
STATEMENT OF OWNERSHIP, MANAGEMENT AND CIRCULATION
}

(Required by 39 U.S.C. 3685)

1. A. Title of Publication: International Organization

B. Publication No.: 00208183

2. Date of Filing: $9 / 27 / 90$

3. Frequency of Issue: Quarterly; Winter. Spring, Summer, Fall

A. No. of issues published annually: Four

B. Annual subscription price: $\$ 28 /$ Ind $\$ 60 /$ Inst

4. Location of known office of publication (not printer): MIT Press, 55 Hayward Street, Cambridge, Middlesex, MA 02142-1399

5. Location of Headquarters of General Business Office of the publisher (not printer): same as item 4

6. Names and Complete Addresses of Publisher, Editor, and Managing Editor:

Publisher: MIT Press, 55 Hayward Street, Cambridge, MA 02142-1399

Editor: Stephen Krasner, Stanford University, Dept. Poli. Sci. Bldg. 160, Serra Street, Stanford, CA 94305

Managing Editor: Sharon Maddox, Stanford University, Dept. Poli. Sci. Bldg. 160, Serra Street, Stanford, CA 94305

7. Owner (if owned by a corporation, its name and address must be stated and also immediately thereunder the names and addresses of stock-holders owning or holding 1 percent or more of total amount of stock. If not owned by a corporation, the names and addresses of the individual owners must be given. If owned by a partnership or other unincorporated firm, its name and address, as well as that of each individual, must be given. If the publication is published by a nonprofit organization, its name and address must be stated.): MIT Press, 55 Hayward Street, Cambridge, MA 02142-1399 and World Peace Foundation, 22 Batterymarch St., Boston, MA 02109

8. Known bondholders, mortgagees, and other security holders owning or holding 1 percent or more of total amount of bonds, mortgages, or other securities: None

9. For completion by nonprofit organizations authorized to mail at special rates: Has not changed during preceding 12 months

10. Extent and nature of circulation:

A. Total number of copies printed (not press run):

Average number of copies each issue during preceding 12 months: 3060

Actual number of copies of single issue published nearest to filing date: 3248

B. Paid and/or requested circulation:

1. Sales through dealers and carriers, street vendors and counter sales: Average number of copies each issue during preceding 12 months: 0

Actual number of copies of single issue published nearest to filing date: 0

2. Mail Subscriptions: Average number of copies each issue during preceding 12 months: 2521 Actual number of copies of single issue published nearest to filing date: 2777

C. Total paid circulation: Average number of copies each issue during preceding 12 months: 2521 Actual number of copies of single issue published nearest to filing date: 2777

D. Free distribution by mail, carrier or other means-samples, complimentary and other free copies: Average number of copies each issue during preceding 12 months: 110 Actual number of copies of single issue published nearest to filing date: 124

E. Total distribution (Sum of $\mathrm{C}$ and $\mathrm{D}$ ): Average number of copies each issue during preceding 12 months: 2631

Actual number of copies of single issue published nearest to filing date: 2901

F. Copies not distributed:

1. Office use, left-over, unaccounted, spoiled after printing: Average number of copies each issue during preceding 12 months: 429

Actual number of copies of single issue published nearest to filing date: 347

2. Returns from news agents: Average number of copies each issue during preceding 12 months: 0

Actual number of copies of single issue published nearest to filing date: 0

G. Total (Sum of E and F-should equal net press run shown in A): Average number of copies each issue during preceding 12 months: 3060

Actual number of copies of single issue published nearest to filing date: 3248

I certify that the statements made above by me are correct and complete.

Dorothy Devereaux

Circulation Manager 


\section{Now published by the Johns Hopkins University Press for the Center of International Studies}

\section{WORLD POLITICS}

A Quarterly Joumal of Intermational Relations

Henry S. Bienen, Editor

Since 1948, World Politics has offered analytical and theoretical articles, research notes, and review articles in international relations, comparative politics, political theory, foreign policy, and modernization, as well as in history, geography, economics, military affairs, and sociology.

Under the editorial sponsorship of the Center of International Studies at Princeton University, World Politics publishes original papers on the frontiers of research and scholarship. Current articles include "Soviet Federalism and Ethnic Mobilization," "Explaining Third World Alignment," and "The Security

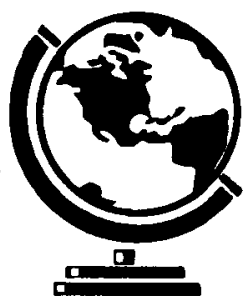
Problematic of the Third World."

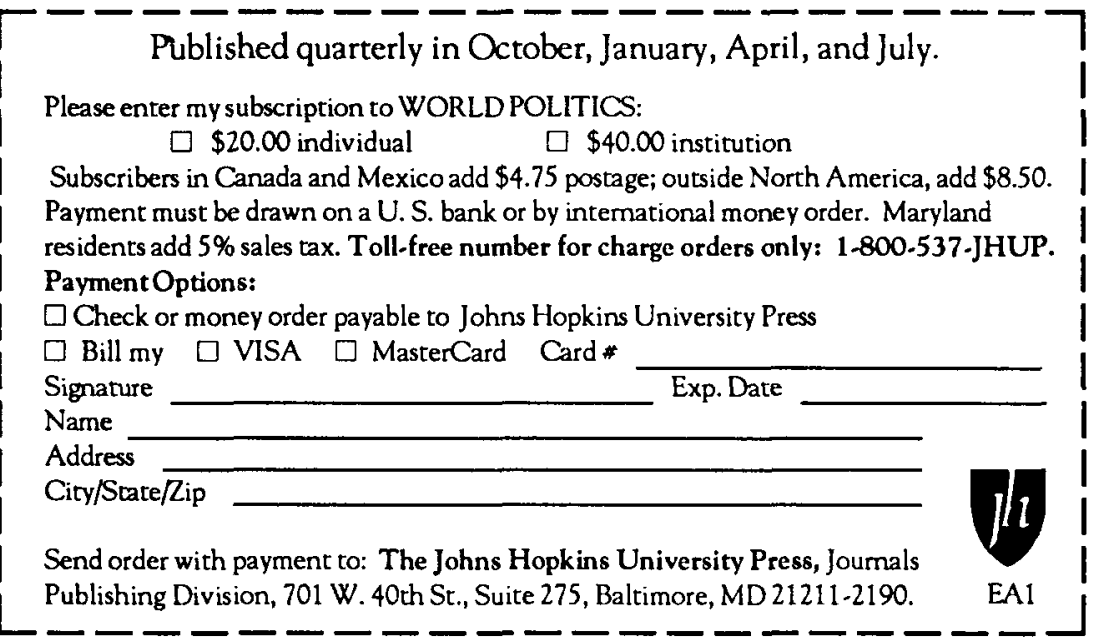




\section{NEW FROM MIT}

\section{TAKING MONEY SERIOUSLY David Laidler}

Putting the "matters" back into "money matters" is David Laidler's intent in this collection of ten essays on the role of monetary institutions in the development of monetary theory and the implications of these ideas for policy. Together, the essays provide a coherent and accessible introduction to the power and range of thinking by one of the world's leading monetary economists.

200 pp. $\quad \$ 27.50$

\section{SOCIALLY RELEVANT POLICY ANALYSIS}

Structuralist Computable General Equilibrium Models for the Developing World

\section{edifed by Lance Taylor}

"Taylor is very original, and his attempt at going beyond the straightjacket of most neoclassical CGEs is most welcome and useful."

- Jaime de Melo, Senior Economist, The World Bank

379 pp. $\quad \$ 37.50$

\section{NEW DEVELOPMENTS IN THE LABOR MARKET}

Toward a New Institutional Paradigm

edited by Katharine Abraham and Robert McKersie

These original contributions report on new developments taking place in today's labor market and on the role of public policy in shaping that process.

300 pp. $\quad \$ 32.50$ (December)
GROWTH/PRODUCTIVITY/ UNEMPLOYMENT

\section{edited by Peter Diamond}

Robert Solow received the Nobel Prize in economics in 1987, and his contributions to growth theory, productivity, and short run macroeconomics have influenced an entire generation of scholars. The essays in this book extend and elaborate on many of the important ideas Solow has either originated or developed in the past three decades.

300 pp. $\quad \$ 30.00$ (Deceimber)

\section{SELLING PUBLIC ENTERPRISE} A Cost/Benefit Methodology Leroy Jones, Pankaj Tandon, and Ingo Vogelsang

Selling Public Enterprise uses economic logic to develop a quantitative approach to making divestiture decisions.

264 pp. $\$ 27.50$

Now available in Paperback

MARKETS OR GOVERNMENTS CHOOSING BETWEEN IMPERFECT ALTERNATIVES

\section{Charles Wolf, Jr.}

248 pp. $\$ 10.95$ paper (November)

To order call toll-free

1-800-356-0343

or (617) 625-8569

Fax orders: (617) 625-6660 MasterCard and Visa accepted.

\section{The MIT Press}

55 Hayward Street, Cambridge, Massachusetts 02142 


\section{MIT Press Journals Presents International Organization/Back Issues Available}

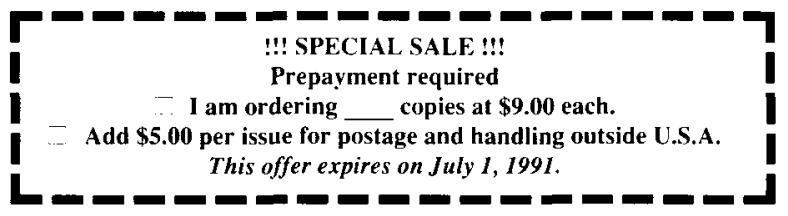

\section{Featured Articles}

\section{Vol. 33, No. 1, Winter 1979}

The Political Consequences of the Product Cycle: Industrial History and Political Outcomes James R. Kurth

\section{Vol. 33, No. 2, Spring 1979}

Transnational Corporations and the Political Economy of Export Promotion:

The Case of the Mexican Automobile Industry Douglas Bennett, Kenneth E. Sharpe

\section{Vol. 33, No. 3, Summer 1979}

The Management of Surplus Capacity:

Or How Does Theory Stand Up to

Protectionism 1970s Style? Susan Strange

\section{Vol. 33, No. 4, Autumn 1979}

An Economic Theory of Mutually,

Advantageous Issue Linkages in

International Negotiations Robert D.

Tollison, Thomas D. Willett

\section{Vol. 34, No. 2, Spring 1980}

Latin American Trade Negotiations with the United States John S. Odell

Self-Reliance in Theory and Practice in Tanzanian Trade Relations

Thomas J. Biersteker

\section{Vol. 34, No. 4, Autumn 1980}

Interdependence and Power: A Conceptual Analysis David A. Baldwin Capitalism in One Country? Switzerland in the International Economy Peter $\mathbf{J}$.

Katzenstein

\section{Vol. 35, No. 2, Spring 1981}

Modeling OPEC Behavior: Economic and Political Alternatives Theodore H. Moran Sphere of Flying: The Politics of International Aviation Christer Jönsson

\section{Vol. 35, No. 3, Summer 1981}

Third World Indebted Industrialization: International Finance and State Capitalism in Mexico. Brazil, Algeria, and South Korea Jeff Frieden

\section{Vol. 35, No. 4, Autumn 1981}

The GATT and the Regulation of Trade Barriers: Regime Dynamics and Functions Jock A. Finlayson, Mark W. Zacher Recent Trends in U.N. Human Rights Activity: Description and Polemic Jack Donnelly

\section{Vol. 36, No. 1, Winter 1982}

On the Notion of "Interest" in International Relations Friedrich Kratochwil

The Political Economy of Indian Joint Industrial Ventures Abroad Dennis J. Encarnation

\section{Vol. 36, No. 3, Summer 1982}

Managing the Global Commons

Per Magnus Wijkman

Between Dependency and Autonomy:

India's Experience with the International

Computer Industry' Joseph M. Grieco

\section{Vol. 36, No. 4, Autumn 1982}

Capitalism and Hegemony: Yorwbaland and the International Economy David D. Laitin

\section{Vol. 37, No. 1, Winter 1983}

Hegemonic Stability Theory and

Nineteenth-Century Tariff Levels in

Europe Timothy J. McKeown

\section{Vol. 37, No. 4, Autumn 1983}

The Unraveling of the Multi-Fiher

Arrangement, 1981: An Examination of

International Regime Change

Vinod K. Aggarwal 


\section{Vol. 38, No. 1, Winter 1984}

The Origins and Development of the Northeast Asian Political Economy: Industrial Sectors, Product Cycles, and Political Consequences Bruce Cumings Breaking with Orthodoxy: The Politics of Economic Policy Responses to the Depression of the 1930s Peter Alexis Gourevitch

\section{Vol. 38, No. 2, Spring 1984}

The Poverty of Neorealism

Richard K. Ashley

The Hegemon's Dilemma: Great Britain, the United States, and the International Economic Order Arthur A. Stein

\section{Vol. 38, No. 3, Summer 1984}

Policy Coordination by Major Western Powers in Bargaining with the Third World: Debt Relief and the Common Fund Barbara B. Crane

\section{Vol. 38, No. 4, Autumn 1984}

Economic Structure and International Security: The Limits of the Liberal Case Barry Buzan

The Force of Prescriptions Friedrich Kratochwil

\section{Vol. 39, No. 1, Winter 1985}

The Empire Strikes Back: The Transformation of the Eastern Bloc from a Soviet Asset to a Soviet Liability Valerie Bunce

\section{Vol. 39, No. 4, Autumn 1985}

The Limits of Hegemonic Stability

Theory Duncan Snidal

\section{Vol. 40, No. 1, Winter 1986}

Reciprocity in International Relations

Robert O. Keohane

Neomercantilism and International

Economic Stability Paolo Guerrieri,

Pier Carlo Padoan

\section{Vol. 40, No. 3, Summer 1986}

International Human Rights: A Regime Analysis Jack Donnelly

What Is Nationalism and Why Should We Study It? Emst B. Haas

\section{Vol. 41, No. 1, Winter 1987}

Crisis Prevention and the Austrian State

Treaty Deborah Welch Larson

\section{Vol. 41, No. 4, Autumn 1987}

Quasi-States, Dual Regimes, and

Neoclassical Theory: International Jurisprudence and the Third World Robert H. Jackson

Resisting the Protectionist Temptation: Industry and the Making of Trade Policy in France and the United States during the 1970s Helen Milner

\section{Vol. 43, No. 1, Winter 1989}

The Impact of Ideas on Trade Policy: The Origins of U.S. Agricultural and Manufacturing Policies Judith Goldstein

Vol. 44, No. 1, Winter 1990

Is World Politics Evolw' ary Learning? George Modela ${ }_{10} \mathbf{O C}$ Neither Mr Sol Economy of upital Liberalization in Japan Dennis J. Encarnation, Mark Mason

\section{Vol. 44, No. 2, Spring 1990}

Chain Gangs and Passed Bucks: Predicting Alliance Patterns in Multipolarity Thomas J. Christensen, Jack Snyder The International Telecommunications Regime: The Political Roots of Regimes for High Technology Peter F. Cowhey

\section{Vol. 44, No. 3, Summer 1990}

Socialization and Hegemonic Power G. John Ikenberry, Charles A. Kupchan Multilateral Negotiations: A Spatial Analysis of the Arab-Israeli Dispute Bruce Bueno de Mesquita

Prepayment is required.

Back issues are $\$ 16.00$.

For delivery outside of the U.S.A., please add $\$ 5.00$ postage and handling per issue.

Make check or money order payable to

INTERNATIONAL ORGANIZATION and mail to:

MIT PRESS JOURNALS S5 HAYWARD STREET CAMBRIDGE, MA 02142 U.S.A. 


\section{American Journal of Political Science}

Journal of the Midwest Political Science Association Editor: David Rohde, Michigan State University

The American Journal of Political Science is one of the leading journals of political science, publishing works on American and international politics, methodology, and political philosophy. In addition to regular articles, AJPS features a "Workshop" section with review essays, spirited exchanges on controversial topics, and discussions of methodological and theoretical questions.

\section{Volume 34, Number 1, February 1990}

The Roots of Public Opinion Toward New Social Movements: An Empirical Test of Competing Explanations by Robert Rohrschneider A Dead Senator Tells No Lies: Seniority and the Distribution of Federal Benefits by Brian E. Roberts

Resource Allocation in Multiparty Elections by James M. Snyder

\section{Volume 34, Number 2, May 1990}

Issue Linkages in International Crisis Bargaining by T. Clifton Morgan

The Effects of Campaign Spending in House Elections: New Evidence for Old Arguments by Gary C. Jacobson

Rebuttal to Jacobson's "New Evidence for Old Arguments" by Donald Philip Green and Jonathan S. Krasno

Individual single copy rate $/ \$ 8$, Institution single copy rate $/ \$ 11$, Outside USA, add $\$ 1.50$ for postage.

Subscription rates (one year): Individual $/ \$ 20$, Institution $\$ 40$, Family $/ \$ 20$, Student $/ \$ 12$, Outside USA, add $\$ 4$ for postage.

University of Texas Press, Journals Dept., Box 7819, Austin, Texas 78713 


\section{KEEP INFORMED!}

Whether your main interest is international relations, business or finance, you can't afford to be without the timely, authoritative and influential articles in INTERNATIONAL ORGANIZATION. Don't wait for borrowed copies or hurry to return them. Order your personal subscription today and join the experts in universities, embassies, corporations and international think tanks who must read INTERNATIONAL ORGANIZATION to keep informed of today's shifting alliances and international market activity.

SUBSCRIBE TODAY TO INTERNATIONAL ORGANIZATION!

\section{International Organization}

\begin{tabular}{lrll}
\hline Please & $\square$ begin my subscription & Prepayment required & \\
& $\square$ renew my subscription & $\square$ payment enclosed & \\
& & $\square$ charge to my & \\
$\square$ individual & $\$ 28.00$ & $\square$ MasterCard & \\
$\square$ institution & $\$ 60.00$ & $\square$ VISA & \\
$\square$ student/retired & $\$ 20.00$ & card $\#$ & \\
$\square$ Add $\$ 14.00$ postage and & signature \\
handling outside U.S.A. & & \\
\hline BC91 & & \\
Name &
\end{tabular}

Address

Zip Code

\section{International Organization}

Please send the following issues of INTERNATIONAL ORGANIZATION at the back issue price of $\$ 16.00$ each:

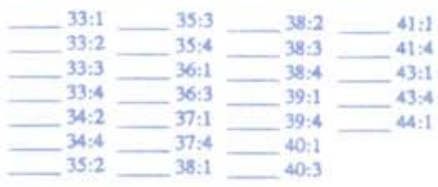

$\square$ I am ordering __ copies at $\$ 16.00$ each

$\square$ Add $\$ 5.00$ per issue for postage and handling outside U.S.A.

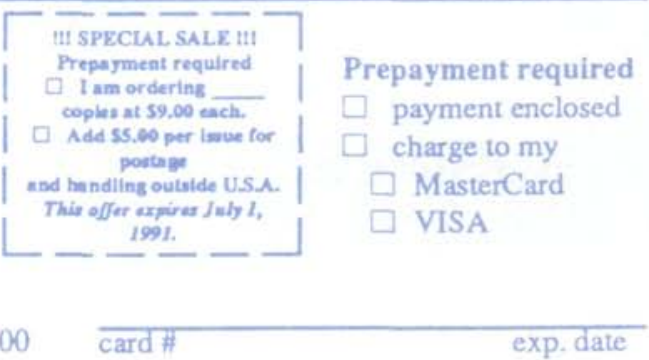

signature

Name

Address 


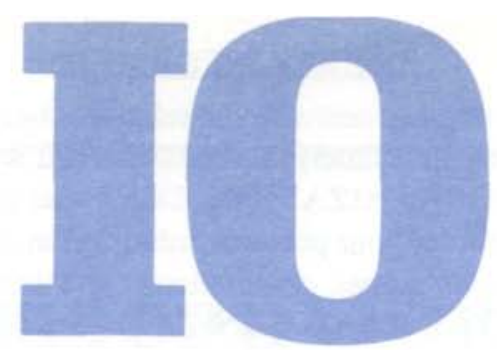

\section{International Organization}

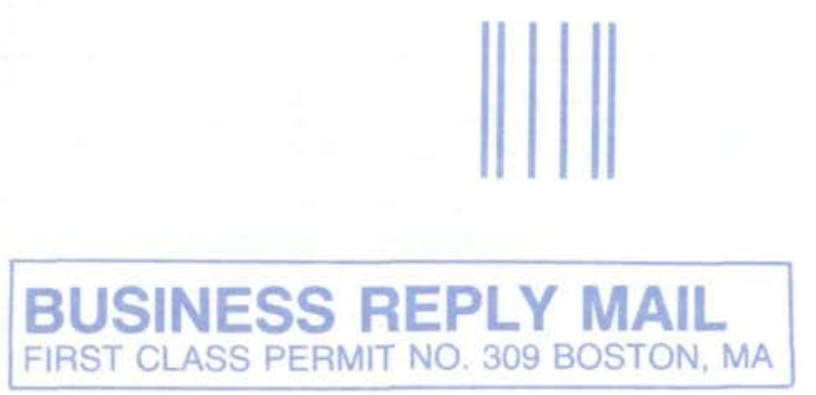

NO POSTAGE NECESSARY

IF MAILED

IN THE

UNITED STATES

POSTAGE WILL BE PAID BY ADDRESSEE

MIT Press Journals

55 Hayward Street

Cambridge. MA 02142-9949

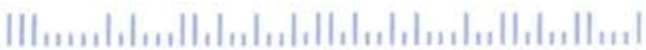

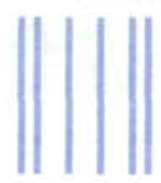

\section{BUSINESS REPLY MAIL}

FIRST CLASS PERMIT NO. 309 BOSTON, MA

NO POSTAGE NECESSARY

IF MAILED

IN THE

UNITED STATES

POSTAGE WILL BE PAID BY ADDRESSEE

\section{MIT Press Journals}

55 Hayward Street

Cambridge. MA 02142-9949

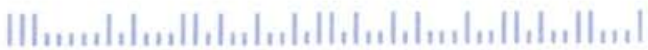




\author{
A Journal of \\ Political and \\ Economic Affairs \\ Sponsored by the \\ World Peace Foundation \\ Edited at Stanford University \\ Published by The MIT Press
}

